\title{
Regulating social media in Nigeria: A quantitative perception study
}

\author{
Mohammed Abdullateef \\ Department of Mass Communication, Nile University of Nigeria \\ muhammedabdul@nileuniversity.edu.ng
}

\section{Abstract}

The advent of social networks as Blogs, Facebook, Twitter, Instagram, WhatsApp, among others, has revolutionized communications. The power of social media messages rests on its ability to instantly and simultaneously reach a wide, diverse audience, and transforming social life. While the public has overtime become accustomed to the regulation of conventional media like the Radio, TV and Print establishments by government regulatory agencies, the idea of regulating social media, a space which many users consider to be the major avenue to air their views, is one that has generated mixed feelings. This study seeks to understand the perception of everyday Nigerian social media users towards government's attempt to regulation social media, amidst the recently proposed Social Media Regulation Bill by the Nigerian lawmakers. The respondents randomly selected for this study were the University of Abuja students and the researcher adopted the survey research design to collect information from the population through questionnaires. The findings indicated that despite respondents' awareness of the possible demerits of an unregulated social media, majority of them (54\%) kick against the idea of social media regulation, while a substantial $(46 \%)$ support the move on the provision that it is not politicized. The study therefore recommends transparency and openness on the part of government officials for better cooperation by the public.

Keywords: Media regulation, Social media regulation, Free speech, Social media bill.

\section{Introduction}

According to World Internet Stats (2020), Nigeria ranks 6th in the global list of Internet usage. Internet users in Nigeria as at 30 June 2019 are put at 123,486,615 with a decade growth rate of 61 percent. This impressive growth rate is not unconnected to the active use of Internet for diverse 
range of social engagements on a daily basis, some of which include mobile shopping, online transactions, work related activities and social interactions on Internet forums and social media platforms such as Facebook, Instagram, Twitter, Snapchat, Whatsapp, Youtube and others.

The Nigerian Senate on 5 November 2019 re-introduced a bill that will regulate the use of social media in the country. The bill, 'Protection from Internet Falsehood and Manipulations Bill 2019' was sponsored by Senator Mohammed Sani Musa representing Niger State East Senatorial District and backed by others; Ibrahim Gobir (Sokoto East), Abba Moro (Benue South), Elisha Abbo (Adamawa North) Bala Na'Allah (Kebbi South). The bill seeks to protect against the transmission of false statement of facts that affect the security, public health, public safety, public tranquillity or public finances of Nigeria. It also seeks to prohibit the transmission of information that affects Nigeria's external relations, influences the outcome of an election, incites feeling of enmity, hatred between persons and groups or diminish public confidence in the performance of duties by the government. In the case where the offender is an individual, he/she is liable to three years' imprisonment or a fine of N300,000 or both. In any other case, the fine is 10 Million. Despite having faced criticisms by activists and some social media users, on 20 November 2019, the bill scaled second reading and has been handed to the Senate Committee on Judiciary, Human Rights and Legal Matters for assessment and report.

The fact that some members of the National Assembly advocate for the regulation of social media does not mean that users are confident that the move is in their interest. The scepticism of Nigerians reflects a general perception about social media regulation, which has been well captured in the literature. Balkin (2020) finds that people have different opinions regarding the regulation of the different social platforms. While existing research like that of Allcott and Gentzkow (2017), (Gainous, Wagner and Gray2016), amongst others, has been useful in weighing the positive and negative consequences of social media regulation, a significant number of these results are limited largely to western social media contexts. Even the popular go-to website for global attitude surveys on media, Pewresearch.org, majorly focuses on the American audience (Pew Research Centre, 2020).

The emergence of the debate in Nigeria contributes to the burgeoning literature about attitudes to social media regulation. The question therefore arises: What does the typical Nigerian social media user think about the regulation of social media in Nigeria by government and what effect will it have on their usage habit? This study aims to understand the perception of everyday social media users in Nigeria regarding social media regulation in the country. Particularly their 
conception of what social media regulation means, their support for or against it, and the effect they think the regulation may have on their usage of social media.

Social media: evolution and social transformations

Social media consists of computer-based technologies for easy communication, interaction and collaboration. They are digitally-mediated communication software that enable users to create, share and view content in publicly networked one-to-one, one-to-many, and/or many-to-many communications (Hopkins, 2017). The social media as we have it today, evolved in generations. Internet use in the early 1990s was mainly a one way flow communication system. Users could only read through contents posted online without a means to participate by either liking, commenting, sharing or interacting with other users. Cormode and Krishnamurthy (2008) explains that Internet use was primarily configured around "passive" consumption of static content posted on websites without any meaningful input or interaction on the part of the content's readers or viewers and this era marks the first generation in the evolution referred to as "Web 1.0"

The late 1990s and early 2000s saw the emergence of the second generation of the evolution of the Internet known as the 'Web 2.0'. This era of Internet evolution is characterized by feedback, interactivity and multimediality. Yar Majid (2018), puts it that what distinguished Web 2.0 platforms, applications, and services from their predecessors was their erosion (and possible effacement) of the distinction between producers and consumers of content, with users generating their own multi-media content (e.g., text, images, animations, audio-visual recordings). This could be shared with multiple other users and it is precisely the user interactivity that puts the "social" into "social media." Notable among the social networking sites in vogue today that exhibits the above described features of the Web 2.0 and more includes: Facebook, YouTube, WhatsApp Twitter, Intsagram, Snapchat, Flickr, Tumblr, Skype, Linkedln, Telegram, Reddit, MySpace, Viber, and many others.

Social impacts of the social media are evident across several countries of the world. The Arab spring became a reference point in many discourses given the role it played in amplifying and accelerating regime changes in Tunisia, Egypt and Libya. Al-Jenaibi (2014) in a survey of respondents from the Arab region found that social media outlets complemented old media and served as a catalyst for the uprisings that have swept several Arab states in the Middle East. Social media was used to mobilize for rioting, street protests and violence in Hungary in 2006. During this period, radical political and cultural groups used the Internet for exchanging 
information, mobilizing supporters and developing their narratives of the events (Jakubowicz, 2012) cited in (Agbaenyi, Okafor \& Nwagbo, 2015).In a bid to assess the relationship between social media use and political knowledge among the Turkish electorate, Andı, Aytaç and Çarkoğlu (2019) found that social media use is positively associated with higher levels of political knowledge and participation. The challenge, however, was that users are more likely to be misinformed and more likely to be opinionated about politics than non-users (Andı, Aytaç \& Çarkoğlu, 2019).

In Nigeria, studies like Oloyede and Elega (2020) explores the impact of social media hashtags, like the \#EndSars on awareness creation about police extortion, rape, assault, and extra judicial killings, ultimately leading to the disbandment of the Special Anti-Robbery Squad (SARS). Nigeria has also witnessed significant improvement in political participation over the years due to the advent of the social media. Agbaenyi, Okafor and Nwagbo (2015) attributed the victory of the opposition party (APC) in the $\mathbf{2 0 1 5}$ general elections to the use of social media by political actors for transmitting campaign promises and exposing some ills of the incumbent government and its party to the people as opposed to the mainstream media that were mostly in controlled by the incumbent government.

Despite the positives of the social media, there have been several agitations for its regulation not just by individuals, but also by governments around the world. The 2013 Defamation Acts enacted by the UK government was prompted by defamation activities by individuals on social media (Chin, 2013). The 'dark side' of social media includes cyber-bullying, manipulation of elections, fear of missing out, social media addiction and the distribution of fake news, therefore an independent, reliable and universal regulatory framework that applies equally to all social media companies must be created (Baccarella, Wagner, Kietzmann \& McCarthy, 2019). Also calling for intervention are researchers O'Keeffe and Clarke-Pearson(2011) who disclosed in their 2011 report that pre-teens and teens who spend a great deal of time on social media sites, such as Facebook, begin to exhibit classic symptoms of depression triggered by the intensity of the online world, thereby putting them at risk of social isolation which in turn leads them to risky social media sites for "help" that may promote substance abuse, unsafe sexual practices, aggressive or self-destructive behaviours. (0'Keeffe \& Clarke-Pearson, 2011). In the same vein, Goodwina, Lemolaa and Ben-Ezrab (2017) call for interventions that target social media use by citizens of France, particularly amongst those most vulnerable to distress. Findings from their research indicates a significant impact of media use on traumas and sleep disorders following the 2015 Batlacan terror attacks in Paris France. 
The Economic Times Newspaper of India reported the Indian Prime Minister's speech about plans to regulate social media to prevent "unimaginable disruption" to the Indian democracy. The regulations, according to the Prime Minister, will be targeted particularly at Twitter and Facebook to "curb growing threats to individual rights and nation's integrity, sovereignty, and security" (Economic Times, October. 22, 2019). Social media have been described by Allcott and Gentzkow (2017) as the "market for fake news." The researchers estimated that the average US adult read and remembered on the order of one or perhaps several fake news articles during the election period, with higher exposure to pro-Trump articles than pro-Clinton articles and this affected the outcome of the 2016 presidential election. While acknowledging that Cyber bullying, stalking, trolling, spam, fraudulent accounts creation and invasion of privacy are now prevalent due to the advent of social media platforms, Osuigwe (2018) argues that self-regulation on the part of the Internet platform companies would be most effective. Regulations to guide content and respect of the privacy of users of the platforms would best be done by the providers of the platforms as government regulations might lead to censorship and information 'sterilization' (Osuigwe, 2018). The contrasting viewpoints by communication researchers and media experts are indications of why the task to regulate activities of social media users has been, and will most likely continue to be an uphill battle for governments and policy makers worldwide.

Another modern day venture that has been argued by media scholars to have contributed to calls for social media regulation is citizen journalism. The rise of citizen journalism has prompted governments around the world to use security concerns (privacy, disclosure of sensitive information) as a rationale for interfering with social media platforms like Facebook, Twitter, Youtube and Instagram (Paslawsky, 2017).This alternate form of journalism is described by Radsch (2013) as the activist form of newsgathering and reporting that functions outside mainstream media institutions, often as repose to shortcoming in the professional journalistic field, that uses similar journalistic practices but is driven by different objectives and ideals and relies on alternative sources of legitimacy than traditional or mainstream journalism.

On the one hand, this form of journalism allows for ordinary people to gather, analyze and disseminate news and information and is valued for enabling participation and providing alternative source of news, but on the other hand, may lead to fake news and disinformation:

Potential false news reports are just one of the many possible ramifications of sourcing news from anonymous sources. The news could be factually correct, but have flaws like blatant disregard of ethics, lack of objectivity, impartiality 


\begin{abstract}
and balance. It could also be a hidden agenda or opinion sugarcoated as fact or a libelous or defamatory statement that puts subjects in the story in bad light. In mainstream media, a process of verification and checks called gate-keeping can weed out any such inaccuracies and biases. Gate keeping, so it's called, is done by experienced and trained journalists and editors, using tools and skills like knowledge of the law and in house or commercial stylebooks such as the Associated Press Stylebook(cited in Okoro, 2013).
\end{abstract}

The paraphrased following is the UNESCO Report that addresses why regulatory bodies and press councils worldwide find it difficult to regulate the activities of citizen journalists:

- Media councils or regulatory agencies were set up primarily to deal with traditional forms of media (mainly print and broadcast), thus there is no prior measure set aside regulate online contents.

- Online news bloggers and citizen journalists rarely sign up to the various existing regulatory councils or systems.

- Some press councils are strict about only dealing with complaints about their members: publishers, titles or sometimes individual journalists who 'sign up' to the rules.

- Lack of resources to handle complaints about the increasing number of harmful online contents.

- Press councils find it difficult to reach a defined line between Journalism and Communication: In drawing a line between the former and the latter, some puzzling questions spring up: is it possible to practice journalism non-voluntarily or even unconsciously online? If so, what are the regulatory and legal implications of this? Is there a need to develop different ethical standards for these new forms of journalism? Can and should citizen journalists or bloggers be judged according to the same rules as other journalists? (Adeline Hulin - UNESCO Report, 2016).

- These factors and more constitute the reasons for which the imposition of rules to censor the social media space may not be such a bad idea to some, particularly considering the detrimental effects associated with fake news, disinformation and hate speeches.

\title{
Media regulation in Nigeria
}

Nickolas Luhman (2000) described the mass media as those institutions that make use of copying technologies to disseminate information to the public. The definition suggests that 
certain institutions, bodies, organizations are responsible for the production and or dissemination of media messages to the public. In this sense, journalists, reporters and other media professionals are engaged in the business of news reporting and thus make it feasible and painless for government and other authorities to monitor, censor, regulate and even directly or indirectly control the mass media. This was the situation prior to the advent of the social media.

The popular saying "the pen is mightier than the sword" does not only describe the usefulness of information but also points to the fact that information can be as much lethal as it can be valuable. Those with the means of handling any information that is capable of shaping human reality have always been seen as threat by authorities or individuals who understand its import.

Harvey (1999) as cited in Ihechu and Okugo (2013) defines regulation as an intervention by the state in areas of economic, social or cultural life according to whatever political norms are characteristic of that nation state. Regulations may be issued by presidential decree, by religious prescription or by legislative action within a system of representative democracy. Media regulation thus refers to the involvement of the government or related bodies in the affairs of the media (electronic and print) to ensure that they operate in line with a defined standard, norm or custom.

The history of media regulation can be traced back to the 15th century in the Western Europe. The emergence of the printing press at the time was welcomed as it brought to end the strenuous task of copying the church or state manuscript text by hand. The fear of dissent by printers and authors however, led to the issuance of a strict licensing system where people had to be given prior approval by the state to publish and defaulters were considered treasonous and severely punished. The global struggle for human rights from the 16th to 19th century across Europe and North America witnessed the gradual reduction of strict laws that prevented the freedom of information and expression. The emergence of public radio broadcasting, telegraphs and the telephone from the 1920'sbrought about a new dimension of regulation (McQuail, 2010 pp.1-3).

Although personal interests of nation leaders, public statesmen, politicians and other opinion leaders have made it impractical to give an objective justification for the need to regulate the media, bulk of the arguments for its need revolves around the protection of individual and public rights, protection of content consumers, maintenance of law and order and promotion of national unity and development. 
There are several forms in which the media of every nation is being regulated by its government or other bodies. In Nigeria, the body responsible for regulation of the electronic media is the National Broadcasting Commission (NBC). It was set up on August 24, 1992 by Decree 38 majorly to regulate and control the broadcast media by processing applications for the ownership of television and radio stations, allocating licenses for broadcasting, enforcing a standardized broadcasting code to ensure professionalism and sanctioning of defaulters (NBC Code, 2016). Other major press regulatory structures include the Nigerian Press Council (NPC), which functions to enquire into complaints about the press, particularly the print media, and monitor their activities to ensure compliance with the ethical code of conduct. The Nigerian Communications Commission (NCC) on the other hand focuses on telecommunications related services. The Commission is empowered to enforce regulations on matters such as spectrum allocation, authorizations and permits, assignments and licenses, telecommunications related offences and imposition of penalties, charges or fines(Nigerian Communications Act, 2003). Other press laws that regulate activities of the mass media in Nigeria are the laws of Defamation, Sedition, and Obscenity all captured in the Criminal Code Act of 2004. The Official Secrets Act as well as the Copyright Act equally functions to regulate press activities, while the former prohibits the publication of confidential information relating to defence establishments and security installations, the latter prohibits unauthorized access to and use of intellectual properties of others (Beli and Inuwa, 2014).

While the regulation of the mainstream media makes it possible for authorities to checkmate the press, the social media enjoy a substantial level of freedom given that there is no major structure for regulation of the platforms except for the Nigerian Cybercrime Act passed into law in 2015.

Although not specific to social media platforms only, the Cybercrime Act seeks to provide a regulatory framework for the prohibition, prevention, detection, prosecution and punishment of crimes related to computer systems and networks, electronic communications, data and computer programs, intellectual property and privacy rights. The closest regulation that applies to misinformation and posting of harmful content on social media is the Section 24 (1a) that states that any person who knowingly or intentionally sends a message or other matter by means of a computer system or network that is grossly offensive, pornographic or of an indecent, obscene or menacing character or causes any such message or matter to be sent is guilty of an offence and is liable for prosecution. The Subsection (1b) provides that any person who knowingly or intentionally spreads messages or other matter by means of a computer network system that 
he knows to be false, for the purpose of causing annoyance, inconvenience, danger, obstruction, insult, injury, criminal intimidation, enmity, hatred, ill will or needless anxiety to another or causes such a message to be sent is guilty of same offence and shall be liable on conviction to a fine or imprisonment for a term of not more than 3 years or to both such fine and imprisonment(Cybercrime [Prohibition, Prevention, etc.] Act 2015).

Studies like Eboibi(2017) and Adediran (2020) argue that the underutilization of the extant provisions of the Cybercrime Act by prosecutors and law enforcement agents is the reason for a false sense of absolute freedom to misbehave online. The irresponsibility of some social media users has over the years raised concerns bordering on national security as the platforms have been used to spread fake news that have led to conflicts.

In many instances, pictures and videos from different happenings in the past are mischievously used to cause havoc online. (Apuke and Omar, 2020) cited how a graphic image of a mutilated baby killed in Congo Brazzaville in 2012 was shared on Facebook with the claim that the act was carried out by the Fulanis against the Beroms in Jos, Nigeria in 2018, thus, leading to reprisal attacks by Berom youths. The Vanguard Newspaper reported that at least two deaths and 20 hospitalizations followed the viral fake news on social media in 2014 that directed Nigerians to consume and bath with salt water to prevent them from contracting the Ebola virus disease.

Sadiku (2018) as cited in Apuke and Omar (2020) gave the instance where the gruesome murder of over 86 people in 11 communities in Barkin Ladi, Rirom and Jos South Local Government areas of Plateau state was described on social media to be a reprisal attack carried out by the Miyetti Allah (cattle breeders) group. Even though a newer report revealed that the killings had nothing to do with the Miyetti Allah group, the fake news stories had already resulted to further deaths in the state. Another is the viral fake video report indicating that President Muhammadu Buhari had died and had been replaced by a Sudanese double (Anderson, 2019). Apuke and Omar (2020) argues that such fake news like that of the president being a clone, or the one about his plans to marry the finance minister Zainab Ahmed, could destabilize the system, incite people to violence and weaken their confidence in the government administration. Ekwe, et al (2011) cited in Ajayi (2015) holds that the increasing use of social media and other online tools has led to greater privacy challenges and regardless of the potentials of the Internet and other digital social media platforms, there is need for adequate regulation if our society is not to degenerate into a state of anarchy. There is need for clear cut legal framework geared towards preventing the posting of harmful contents online without recourse to age and sensibilities of the users (Olayiwola, 2014). 
In the same vein, Obiorah and Onuigbo (2018) suggest that if the public does not trust the news media, it loses credibility and ultimately the ability to perform the essential "watchdog" role; making it expedient to put in place sets of regulations that addresses the disseminate of disinformation on social media.

The interesting fact about any media regulation discourse, whether in conventional or social media is the unavoidable consideration of the possibility for regulators to violate the basic human rights, such as the right to freedom of expression and speech. The United Nations General Assembly Resolution 59 (1) of December 14, 1946, states that Freedom of information is a fundamental human right and is the touch stone of all the freedoms to which the United Nations is consecrated (Undocs.org, 2021). Similarly, Article 19 of the Universal Declaration of Human Rights of December 10, 1948, states that: "Everyone has the right to freedom of opinion and expression; this right includes freedom to hold opinion without interference; and to seek, receive and impart information and ideas through any media regardless of frontiers" (Un.org 2021). In the same vein, Article 9 of the African Charter on Human and People's Rights, states that: "Every individual shall have the right to receive information and express and disseminate opinions within the framework of the law"(Achpr.org, 2021).

In Nigeria, the Section 39 of the 4th chapter of the Nigerian constitution provides that: "Every person shall be entitled to freedom of expression, including freedom to hold opinions and to receive and impart ideas and information without interference"(Constitution of the Federal Republic of Nigeria 1999). Although the quoted segment of the Nigerian constitution grants the public the right to freedom of expression, the immediate sub sections provides a law limiting these rights and entrusting regulatory powers to state authorities in the event of indiscriminate dissemination of "sensitive" information, contempt of court and of the government, invasion of piracy, and intimidation of government officials:

Nothing in this section shall invalidate any law that is reasonably justifiable in a democratic society - (a) for the purpose of preventing the disclosure. of information received in confidence, maintaining the authority and independence of courts or regulating telephony, wireless broadcasting, television or the exhibition of cinematograph films; or (b) imposing restrictions upon persons holding office under the Government of the Federation or of a State, members of the armed forces of the Federation or members of the Nigeria Police Force or other Government security services or agencies established by law (Constitution of the Federal Republic of Nigeria 1999). 
Debates on the possibility for the violation of human rights in the process of enforcing social media regulations are not one that is unique to Nigeria only but also to many democratic nations across the globe. In addressing this issue, Désir (2018) argues that for social media to be regulated, states must reflect through their laws and policies to ensure that same rights that individuals have offline must be protected online, particularly the right to freedom of expression and access to information. This means that generic bans, compulsory registration of online media outlets, should not be imposed by the state. Secondly, blocking of media outlet's content should have a clear and precise basis in Law; this connotes that all what is deemed to constitute "hate speech", "terrorism tendencies", and extremism should be clearly and narrowly defined in Law and such content blocking should only be authorized by an independent and impartial court with appropriate procedural safeguards under the rule of law. This will be especially effective if the blocking measure is accompanied by information about the reason(s) for such blocking. Thirdly, blocking online contents should pursue a legitimate aim. This can be ascertained when content blocking measures follows the internationally acceptable standards. It is illegitimate for states to block contents that are of public interest or of opposing view to government or religious authorities. Lastly, careful consideration should be made regarding technologies to be used for such regulation, so as not to infringe upon rights to freedom of expression. Courts, tribunals and other regulatory bodies tasked with the responsibility of issuing content blocking orders must equally consider the risks of "over-blocking" by ensuring that such orders are the least restrictive means available, and that list of banned sites duly publicized. (Désir 2018).

\section{The 2019 social media bill}

The bill aims to prevent the transmission of false statements or false declaration of facts with a view to counter the effects of such transmissions in Nigeria. Among the ways of achieving this would be to suppress the financing, promotion and endorsement of whatever is considered a false statement. Measures will be put in place to detect, control and safeguard against coordinated inauthentic behaviour, including the misuse of online accounts, and defaulters will be sanctioned.

The bill equally describes what should be seen by law as constituting a false statement of facts that warrants sanctions. This includes being prejudicial to the security of Nigeria, to public health, public safety, public tranquillity and public finances of the country. Other ways in which one could be liable is by transmitting statements capable of influencing the outcome of an election, inciting feelings of enmity, hatred or ill-will between different groups of persons. One could also be found wanting for transmitting statements prejudicial to the friendly relations of Nigeria with other 
countries or capable of diminishing public confidence in the performance of the government. As punishment, the bill prescribes that a person who defaults shall be guilty of an offence and shall be liable on conviction. In the case of an individual, he/she is liable to 3 years' imprisonment or a fine of $\mathrm{N} 300,000$ or both. In any other case, a fine of 10 million naira.

The bill also specifically targets the issue of providing services for transmission of false statements of fact in Nigeria. It seeks to address the issue of news and information commercialization by the press and more recently; owners and operators of online news media outlets such as social media pages, YouTube channels, websites, blogs and other social network platforms. It read that where a person receives or agrees to receive financial or material reward for providing transmission service(s), knowing that the service(s) is or will be used in the transmission of false statements in Nigeria, shall be guilty of an offence and is liable to a fine of $\mathrm{N} 150,000$ or 3 years imprisonment or both in the case of an individual. In any other case, a fine of N500,000"(Musa, S.N. Protection from Internet Falsehood and Manipulations Bill, 2019).

\section{Methodology}

The survey method was adopted to investigate the perception of social media users among Nigerian students. The population selected for the study were undergraduate students of the University of Abuja, Nigeria. The total undergraduate population of the University of Abuja is 16,602 (Source: UNIABUJA Academic Unit). The Taro Yamane model was used to determine the sample size. The formula for this model is: $n=N / 1+N(e) 2$. Where $n=$ Sample size, $N=$ Population size $(16,602), I=$ Unit in Value (1), e = Estimated standard error margin $(0.05)$, the sample size for the study after the calculation amounted to $(n=390)$. The sampling technique employed was the simple random sampling because it allowed for random selection of a subset of participants from the university undergraduate population. Structured questionnaires were distributed to students across several undergraduate programmes in the university main campus located at Airport Road, Abuja. To assess validity, the instrument was subjected to vetting by experts and thereafter tested in an online pilot study of 20 respondents. The total number of questionnaires administered afterwards was 390 . However, the number of questionnaires duly completed and returned was 355 , amounting to $91 \%$ of the original size. The high return rate was because the questionnaires were administered for four consecutive days in the University campus. The days being 17th, 18th, and 20th March 2020. Meanwhile, the 355 questionnaires were presented and interpreted based on $100 \%$. Descriptive statistics involving tables, charts, percentage distributions and frequency patterns are used to analyse the outcome of the responses from the 


\section{Findings}

Table I: What comes to your mind when you think of Social Media Regulation?

\begin{tabular}{|c|c|c|c|c|c|c|}
\hline Variables & AGREE & & DISAG & & TOTAL & TOTAL \\
\hline & (FRQ) & (\%) & (FRQ) & (\%) & (FRQ) & (\%) \\
\hline Suppression of Public Opinion & 231 & 65 & 124 & 35 & 355 & 100 \\
\hline $\begin{array}{l}\text { An Autocratic System of } \\
\text { Governance }\end{array}$ & 227 & 64 & 128 & 36 & 355 & 100 \\
\hline $\begin{array}{l}\text { Decreased Inclusiveness in } \\
\text { Governance }\end{array}$ & 241 & 68 & 114 & 32 & 355 & 100 \\
\hline Nothing out of the ordinary & 8 & 2 & 347 & 98 & 355 & 100 \\
\hline A safer cyberspace & 244 & 69 & 111 & 31 & 355 & 100 \\
\hline $\begin{array}{l}\text { Reduced rate of fake news and } \\
\text { disinformation }\end{array}$ & 266 & 75 & 89 & 25 & 355 & 100 \\
\hline $\begin{array}{l}\text { Reduced rate of Hate Speech, } \\
\text { Bullying and Violence Online }\end{array}$ & 243 & 69 & 112 & 31 & 355 & 100 \\
\hline
\end{tabular}

The above table is a multiple response table with seven (7) categories that attempts to capture the thoughts that crosses the mind of the average Nigerian upon hearing the phrase "social media regulation". In the first column, some 231 respondents representing $65 \%$ of the respondents agree that social media regulations ultimately leads to suppression of public opinion, while $64 \%$ and $68 \%$ respectively agrees that it potentially leads to autocracy and decreased inclusiveness in governance.

Interestingly, some 244,266 and 243 respondents representing $69 \%, 75 \%$ and $69 \%$ respectively agree that its regulation will lead to safer cyberspace, reduced rate of misinformation and violence online, further proving the trueness of popular assertion that describes social media to be a double-edged sword.

Careful assessment of the retrieved questionnaires on individual response basis showed to the 
researcher that most respondents who agreed with the first three categories in the above table, disagreed with the last three categories and vice versa. This can be likened to Psychologist Louis Guttmans' 1944 scale rule, which states that items can be arranged along a continuum in such a way that a person who agrees with an item or finds an item acceptable will also find acceptable all other items expressing similar positions, while disagreeing with others that are not.

Table II: In your opinion, which of the following commonly used social media platforms in Nigeria is most harmful, and why?

\begin{tabular}{lll}
\hline Variables & Frequency & Percentage \\
\hline Facebook & 122 & $34.4 \%$ \\
Twitter & 154 & $43.4 \%$ \\
WhatsApp & 27 & $7.6 \%$ \\
Instagram & 52 & $14.6 \%$ \\
YouTube & 0 & 0 \\
Total & 355 & $100 \%$ \\
\hline
\end{tabular}

Some 154 respondents representing (43.4\%) opined that Twitter poses greater threats in terms of harmful contents online, while Facebook (34.4\%), Instagram (14.6\%) and Whatsapp (7.6\%) trails accordingly with YouTube recording zero (0). The graph below contains summary of respondents' reasons for their choices of the most harmful social media platforms in Nigeria.

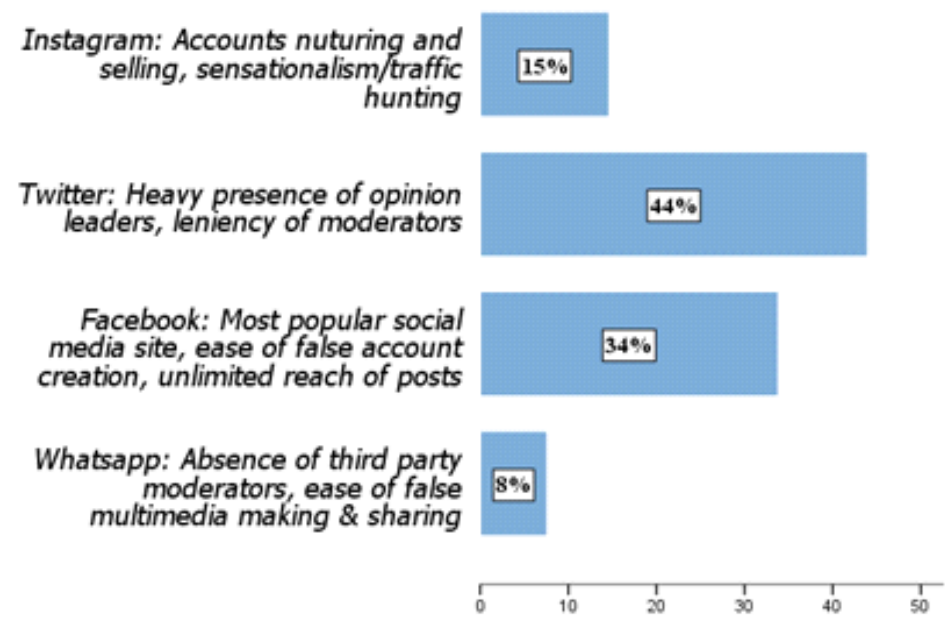


Table III: Do you support the move for government regulation of social media in Nigeria as proposed by Nigerian Lawmakers?

\begin{tabular}{lll}
\hline Variables & Frequency & Percentage \\
\hline Yes & 163 & $46 \%$ \\
No & 192 & $54 \%$ \\
Total & 355 & $100.0 \%$ \\
\hline
\end{tabular}

As can be seen in the above table, some 192 respondents (56\%) do not support the idea, while the 163 others $(46 \%)$ do.

TablelV: How will social media regulation affect your usage habits?

\begin{tabular}{lll}
\hline Variables & Frequency & Percentage \\
\hline $\begin{array}{l}\text { I will have increased interest to access } \\
\text { and use social media platforms }\end{array}$ & 43 & $12.1 \%$ \\
$\begin{array}{l}\text { There will be no change in my social } \\
\text { media access and usage habit }\end{array}$ & 169 & $47.6 \%$ \\
$\begin{array}{l}\text { I will have reduced interest to access } \\
\text { and use social media platforms }\end{array}$ & 139 & $39.2 \%$ \\
I will stop using social media entirely & 4 & $1.1 \%$ \\
Total & 355 & $100 \%$ \\
\hline
\end{tabular}

Data from the above table reveals the possible attitude of respondents with regards to social media usage in the event that is becomes regulated by government. From the table, only 4 respondents (1.1\%) agreed on the likelihood to quit social media entirely. Majority, that is 169 $(47.6 \%)$ and $43(12.1)$ will remain on board, while 139 others representing $39.2 \%$ will not quit social media, but have reduced interest to access and use them. 163 others (46\%) do. 
Figure V: What would you suggest as alternatives to Government regulation of social media in Nigeria?

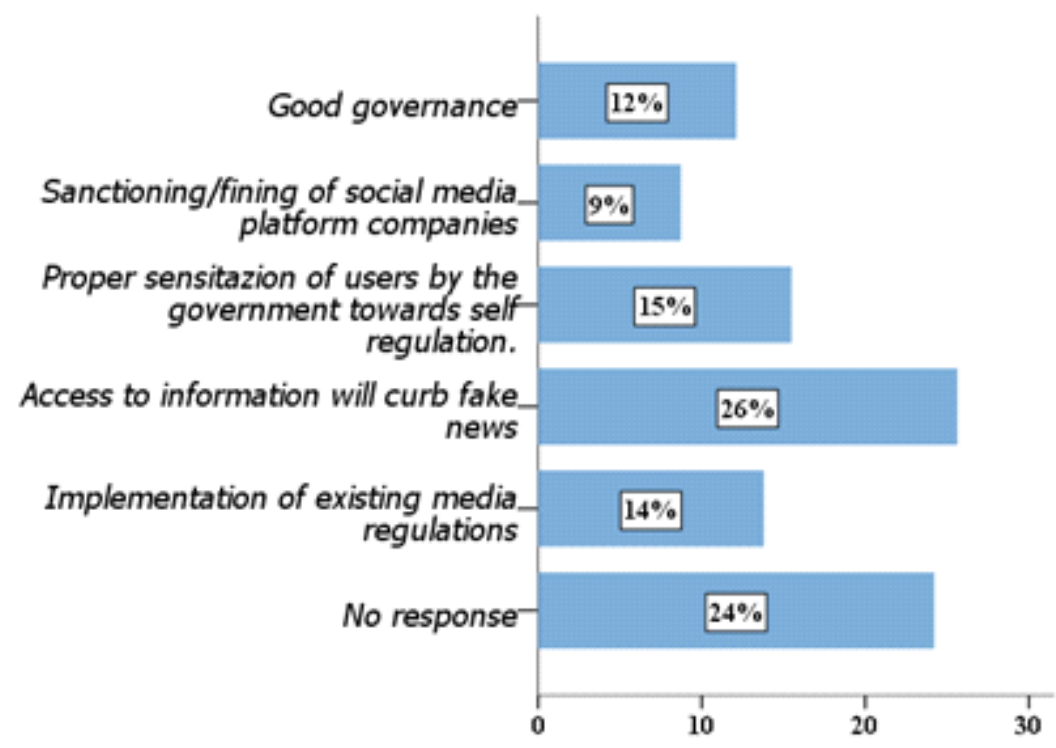

From the graph above, $26 \%$ of the respondents opine that access to information will reduce the effect of fake news, while $15 \%, 12 \%$ and $9 \%$ of the respondents respectively specified Proper Sensitization of users, Good Governance and sanctioning of Social media companies for failing to moderate contents as the best alternatives social media regulation.

Nigeria indeed has several existing constitutionally recognized media laws that may be applicable to crimes on social media, and $14 \%$ of the respondents are calling for the implementations of these laws, rather than new laws that will restrict access and usage of social media in Nigeria.

\section{Discussion of findings}

\section{What does social media regulation mean to Nigerian university undergraduates?}

The responses in Table 1 show some extreme positions. $65 \%$ of the respondents suggested it meant Suppression of Public Opinion to them, while $64 \%$ and $68 \%$ respectively agrees that it potentially leads to Autocracy and Decreased Inclusiveness in Governance. On the not so extreme angle, $69 \%, 75 \%$ and $69 \%$ respectively agree that Social media regulation will lead to a Safer Cyberspace, Reduced Rate of Misinformation and Reduced Rate of Violence online. This reflects 
the interestingly polarized positions of several Nigerians on this matter. This finding re-affirms the arguments of media researcher Nkem Osuigwe who argues that although cyber bullying, stalking, trolling, spam, fraudulent accounts creation and invasion of privacy are now prevalent due to the advent of social media, the government making laws to regulate users' contents might hinder free speech and ultimately lead to censorship and information 'sterilization' (Osuigwe, 2018.).

Also, when there is constant lack of trust between the people and the government as in the case in Nigeria, most, if not all of state proposed or introduced policies tend to be met with fierce criticism, disdain and suspicion by the masses and this is evident in the 2014 Global Attitude Survey by Pew Research Centre, where $66 \%$ of sampled Nigerians reported the government and most of its policies (proposed and implemented) favours the politicians, and are not in the interest of the masses. Africa Division media researcher; Anietie Ewang in her 2019 paper with Human Rights Watch writes that the language of the social media regulation bill would appear to create vague criminal offenses that would allow the authorities to prosecute peaceful criticism of government.

Which of the commonly used social media platforms in Nigeria do they consider most harmful, and why?

The responses in Table II and its corresponding chart shows that Twitter (44\%) takes the lead for the social media platform that poses greater threats to users in terms harmful contents online. The $44 \%$ of respondents who selected Twitter as most harmful social media platform outlined that the presence government officials, politicians, policy makers and virtually all government ministries, agencies and departments makes the medium an avenue for masses to directly display held-in grievances, or for opposition party members and politicians to sensationally oppose government policies, actions or inactions while garnering public support, or for government officials to campaign and politick, all with little to no interference by Twitter moderators, even when such interactions contain bullying, hate speeches, misinformation and violence tendencies.

Some $122(34.4 \%)$ listed the ease with false account creation on Facebook as its greatest undoing. Because the site does not verify the pages of public officers and opinion leaders as obtainable on Twitter, desperate individuals tend to create false accounts in guise of opinion leaders, to either spread malicious information or scam other unsuspecting users, and for a site 
whose contents are of no bounds, this is especially worrisome. Greenberg, (2019) finds that unchecked activities of political trolls, extremists, impersonators, phishing scammers and livestreamed actors of horrific violence puts Facebook on the forefront of most abused social media platforms.

For Instagram, $15 \%$ of the respondents reveal the disturbing trend of users deliberately posting false or sensational stories to popularize their handles (username) and garner followers, then sell these heavily followed handles to other users to simply edit and use or resell, because unlike other platforms where the name and characters of a handle is permanent, Instagram provides users the opportunity to edit and re-edit handles as many times as possible.

The $8 \%$ of respondents that chose WhatsApp mentioned the absence of third party moderators and the ease with multimedia making and sharing as the features that fuels violence and false stories on the platform. This is in tandem with McLaughlin (2019) who finds that WhatsApp encourages "tightness" among users, leading to "homophily" - birds of a feather flocking together, and this characteristic explains why the platform leads to "mobilization in the cause of disinformation and violence".

For YouTube to have recorded zero (0) selection as presented in the table, confirms the likelihood of the effectiveness of some of their strict policies against explicit sexual contents, impersonation, hate and violence, threats and harassments, spam and misleading metadata, and most especially, their stance on copyrighted materials.

Do they support the move for government regulation of social media or not?

Responses in Table Ill shows that despite respondents' awareness and confirmations about some harms (misinformation and hate speech) associated with the use of social media, majority of them (54\%) do not support the move for its regulation by government, while the other substantial $46 \%$ do. The data reflects a rather close margin between both sides. Findings from researches like Balkin (2020) points to why there exist such dilemma in the discourse of whether or not to regulate social media. Balkin (2020) found that divergent views about social media regulations abound because unlike the twentieth-century print and broadcast media that weren't participatory and had audiences who were majorly consumers; the 21st century model, by contrast, involves crowd sourcing and facilitating end user content, thus making users both creators and audiences for the content they produce. It was only natural for the respondents to 
have aligned by the side that best support their social media usage habits.

How will social media regulation affect their social media usage habit?

Responses from Table IV shows that some $43(12.1 \%)$ respondents agreed that they will have increased interest to access and use social media platforms, while 169 (47.6\%) others agree that there will be no change in their social media access and usage habit. 139 others representing $(39.2 \%)$ will not quit social media, but will have reduced interest to access and use the platforms, while $4(1.1 \%)$ others agreed they'd stop using social media in its entirety.

These findings very much agree with that of Arnold (2018) who argues that while government regulations might stifle the exchange of ideas online, other equally important interpersonal businesses and conversations happens on social media every day, thus regulations will not necessarily prevent its usage by users. Regulations will not lead people to vet out sources of information they choose to believe in, nor will it stop them from being gullible [Andrew Arnold, 2018].

\section{What should government consider as alternatives to social media regulation in Nigeria?}

From the responses from Figure $\mathrm{V}$, at least $26 \%$ of the respondents suggested that people will have the facts when governments provide unrestricted access to information, and the effect of fake news and misinformation will greatly reduce. Affirming this position is Cyber Researcher, Alex Campbell (2019) who argues that transparency on the part of governments actively lessen the blow of online disinformation as more aware audiences will engage less with false or inflammatory content.

Another $15 \%$ of the respondents call for proper sensitization of users towards self-regulation as an alternative government regulation of social media. The emphasis on self-regulation on the part of users is not one that is new. Self-regulation entails the obligation of upholding the principles of truth, accuracy, objectivity and fairness when handling information online or offline as well as knowledge about identifying potentially false information by source-tracing and discarding such information to reduce its spread.

Still on alternatives to social media regulation, some $14 \%$ of the respondents advocate the implementation of existing constitutional media laws, rather than the proposal of newer stricter ones that seeks to monitor user conversations online. Other than the already enacted 
"Cybercrimes Act" that seeks to protect Nigerians against cyber terrorism and threats, identity theft and impersonation, document forgery and fraud amongst a host of other computer assisted crimes, there also exist media laws against defamation (slander and libel), making users question the need for further attempts to regulate social media Nigeria.

Good Governance, according to $12 \%$ of the respondents will greatly reduce online crimes in the country. Corroborating this, Adesina (2017), established a nexus between Nigeria's' unemployment data and cybercrime from the human security perspective and concluded that viable policies and programmes by the federal government aimed at poverty reduction and eradication, and judiciously backed by actions will greatly deplete rate of crimes and violence online.

Lastly, some $9 \%$ of the respondents emphasized that laws should be made to sanction or fine social media companies who fail to identify and remove misinformation on their platforms. This practice is obtainable in Germany where the "NetzDG law" was created to fine any social media company with 2 million users and above for the sum of $£ 50 \mathrm{~m}$ whenever illegal contents are not removed by moderators after 24 hours. Under the "2019 Abhorrent Violent Material Act" in Australia, there are criminal penalties for social media companies, such as possible jail terms and a fine of $10 \%$ of the company's global turnover! These measures could as well be adopted as alternatives to direct involvement of government to content monitoring, to prevent possible politicization of social media regulation.

\section{Conclusion}

The study set out to understand the perception of Nigerians towards social media regulation, particularly their conception and notion of it, their projected consequences of it, and their ideas about alternatives to it. To prevent one-dimensional responses, the researcher set questions that required respondents to comment on the interestingly polarized (positive and negative) aspects of social media regulation, yet, majority (54\%) of the respondents do not support the move for government regulation of social media in Nigeria. The researcher observed an increasing lack of trust between the people and government, as many respondents fear for the possibility of officials in charge to create vague criminal offenses that would allow the authorities to prosecute peaceful criticisms of government, if social media were to be regulated. This study also proves that users are not unaware of the risks or dangers associated with the use of an unregulated social media, but it is a gamble that most are prepared to take for a free voice online. 
This study also reveals that the worst that could happen if social media were to be regulated is the stifling of the exchange of opposing ideas online, other than that, most respondents will not be discouraged from accessing these platforms for other equally important interpersonal businesses and conversations that happens every-day.

To bridge this gap in trust between people and government, there is dire need for government officials to provide unrestricted access to information by abiding to the provisions of the Freedom of Information (FOI) Act. When the public or the press is denied facts by government, it becomes only natural that they to turn towards potentially false sources for information.

Apart from access to information, findings from this study points towards good governance, proper sensitization of users towards self-regulation, sanctioning of irresponsible social media companies operating in Nigeria and implementation of existing media laws online, rather than regulation by way of direct government involvement in the affairs of social media users.

\section{References}

Adediran, A. 0. (2020). Cyberbullying in Nigeria: Examining the Adequacy of Legal Responses. International Journal for the Semiotics of Law-Revue Internationale d e Sémiotique Juridique,

Adesina, 0.S. (2017). Cybercrime and Poverty in Nigeria. Journal of Canadian Social Science,(13), $19-29$

Agbaenyi, A.N., Okafor, U.N. \& Nwagbo, S.N. (2015). Democracy or Democratization? Exploring the Roles of the Conventional and New Media in African Politics. International Journal of Advanced Multidisciplinary Research Report. 1 (1), 1-16.

Ajayi, A.I. \& Adesote, S.A. (2015). The New Social Media And Consolidation Of Democracy In Nigeria: Uses, Potentials And Challenges. Journal of Good Governance and Sustainable Development in Africa, 2 (4), 47-58.

Allcott, H., \& Gentzkow, M. (2017). Social Media and Fake News in the 2016 Election. J J u r nal of Economic Perspectives, 31 (2), 211-236. 
Al-Jenaibi, B. (2014). The nature of Arab public discourse: Social media and the 'Arab Spring.'Journal of Applied Journalism \& Media Studies, 3(2), 241-260.

Andı, S., Aytaç, S. E., \& Çarkoğlu, A. (2019). Internet and social media use and political knowledge: Evidence from Turkey. Mediterranean Politics, 25(5), 579-599.

Arnold, A. (2018). Do We Really Need To Start Regulating Social Media? Retrieved February 20,2021, from https://www.forbes.com/sites/andrewarnold/2018/07/30/do- we-really-needto-start-regulating-social-media/?sh=358e01bd193d

Apuke, 0.D., \& Omar, B. (2020). Fake News Proliferation in Nigeria: Consequences, Motivations, And Prevention Through Awareness Strategies. Humanities \& Social Sciences Reviews, 8(2), 318- 327

Baccarella, C. V., Wagner, T. F., Kietzmann, J. H., \& McCarthy, I. P. (2020). Averting the $\mathrm{r}$ i s e of the dark side of social media: The role of sensitization and regulation. $\quad E$ u r o p e a $n$ Management Journal, 38(1), 3-6.

Balkin, J.M. (2020). How to Regulate and Not Regulate Social Media. Knight First Amendment Institute of Columbia University. Retrieved February 19, 2020 from https://knightcolumbia.org/content/how-to-regulate-and-not-regulate-social-media.

Beli, B.M \& Inuwa, A.T (2014). Media Regulations in Nigeria: The Roadblocks to Freedom Of The Press. Conference Proceeding: Academic Conference on Sustainable Development Vol. 2 No. 1 July 10-11, 2014, M.L. Audu Auditorium, Federal Po l y t e c hn ic, Bauchi, Nigeria.

Campbell, A. (2019). How Data Privacy Laws Can Fight Fake News. Retrieved February 21, 2020 from https://www.justsecurity.org/65795/how-data-privacy-laws-can-fight-fake-news/

Chin, Y.C. (2013). Regulating social media, regulating life (and lives). A report on the workshop. "Social Media, Regulation and Freedom of Expression" Hong Kong Baptist University. 
Constitution of the Federal Republic of Nigeria CAP 23 L.F.N. 2004. Retrieved February 18, 2020from https//publicofficialsfinancialdisclosure.worldbank.org/sites/fdl/files/assets/ law-library-files/Nigeria_Constitution_1999_en.pdf.

Cormode, G., Krishnamurthy, B. (2018). Key differences between Web 1.0 and Web 2.0. Retrieved January $19, \quad 2020$ from: https://firstmonday.org/ojs/index.php/fm/article/download/2125/1972

Cybercrimes (Prohibition, Prevention, Etc) Act, (2015). Retrieved March 18, 2021 from https://www.cert.gov.ng/ngcert/resources/CyberCrime__Prohibition_Preve ntion_etc_Act_2015.pdf

Eboibi, F. (2017). Curtailing Cybercrime in Nigeria: Applicable Laws and Derivable Sources. African Journal of Criminal Law And Jurisprudence, 2, 14-31

Esimokha, G.A., Benson, B.A., \& Olunika, A. (2019). Perception of Nigerians on Hate Speech Bill: A Study of Akungba-Okoko Residents, Ondo State. IOSR Journal of Humanities and Social Science, $24(11), 59-67$

Ewang, A. (2019). Nigerians Should Say No To Social Media Bill. Retrieved February 21, 2020 from https://www.hrw.org/news/2019/11/26/nigerians-should-say-no-social-media-bill

Gainous, J., Wagner, K.M., \& Gray, T. (2016). Internet freedom and social media effects: Democracy and citizen attitudes in Latin America. Online Information Review, 40 (5), 712738.

Goodwin, R., Lemola, S., \& Ben-Ezra, M. (2018). Media use and insomnia after terror at t a ck s in France. Journal of Psychiatric Research, 98, 47-50

Greenberg, A. (2019). Facebook Let Dozens of Cybercrime Groups Operate in Plain Sight. Retrieved February 21, 2020 from https://www.wired.com/story/facebook- c c y b e r c r i m e groups-again/

Hopkins, J. (2017). How to Define Social Media - An Academic Summary. Retrieved March 19, 2021 from http://julianhopkins.com/how-to-define-social-media-an-academic- 
summary/

Hulin, A. (2016). Citizen Journalism and news blogs: Why Media Councils Do not Care Yet. Retrieved February 19, 2020 from https://blogs.Ise.ac.uk/medialse/2016/06/14/citizenjournalism-and-news-blogs-why-media-councils-dont-care-yet/

Olukolu, R.O., Ogwezzy-Ndisika, A. O., Faustino, B.A., \& Oloruntoba, F.A (2019). Social Media, Regulation and Challenges of Communication in an evolving Nigerian Society. University of Baltimore Journal of Media Law \& Ethics, 7,68-79.

Ihechu, I.P \& Okugo, U.C., (2013). Broadcasting in Nigeria: An Overview of The Approaches. Research on Humanities and Social Sciences, 3 (2), 12-19.

Internet World Stats (2020). Internet Users Statistics for Africa. Retrieved January 11, 202020 from https://www.Internetworldstats.com/stats1.htm

Luhmann, N. (2000). The Reality of the Mass Media, Stanford, CA: Stanford University Press.

McQuail, D. (2010). Media History and Social Regulation. University of Leicester Open Education Resources on Media and Communication. Retrieved January 11, 2020 from https://www2.le.ac.uk/projects/oer/oers/media-and-communication/oers/ms7501/ 2unit11/mod2unit11cg.pdf

Mrabure, K. O. (2016). Countering and Right to Freedom of Expression in Selected Jurisdictions. Nnamdi Azikiwe University Journal of International Law and Jurisprudence. 7, 160-169ISSN: 2276-7371

Musa, S.N. (2019) Protection from Internet Falsehood and Manipulations Bill, Retrieved January 14, 2020 from https://thenigerialawyer.com/wp- content/uploads/2019/11/Protectionfrom- Internet-Falsehood-and-Manipulation- Bill-2019.pdf

NBC, (2016) The National Broadcasting Commission Code. Retrieved February 19, 2020 from https://www.nta.ng/wp-content/uploads/2019/09/1494416213-NBC-Code-6THEDITION.pdf NCC, (2020) The Nigerian Communications Act. Retrieved March 19, 2021 from 
https://www.ncc.gov.ng/accessible/documents/128-nigerian-communications-act- 2003/file Ndubueze, P. N. (2018). Cyber Criminology: Contexts, Concerns and Directions. Ahmadu Bello University Press, Zaria, Nigeria

Obiorah, C., \& Onuigbo, U.U. (2018). Online news Platform and Ethical Flux in Journalism Practice in Nigeria: Legislative and Regulatory Imperatives. Multidisciplinary Journal of Science, Management and Technology, 4, 57-68.

O'Keeffe, G. S., \& Clarke-Pearson, K. (2011). The Impact of Social Media on Children, Adolescents, and Families. Pediatrics, 127(4), 800-804.

Okoro, N. (2013) Citizen Journalism in Nigeria: Possibilities and Challenges. Journal of New Media and Mass Communication, Vol. 11, 1-7.

Olayiwola, V. 0. (2014). Decoding the Potency and of Web 2.0 in Nigeria. International Journal of Politics and Good Governance, 5, 1-14

Oloyede, F., \& Elega, A.A. (2019). Exploring Hashtag Activism in Nigeria: A case of \#Endsars Campaign. Conference Proceeding: 5th in Communication and Media Studies (CRPC 2018)Famagusta, Turkish Republic of Northern Cyprus. Retrieved March 19, 2021 from: https://crcp.emu.edu.tr/Documents/Books/CRCP\%202018\%20Proceeding\%20Book\%2 0 \%20Approved\%200ne.pdf

Osuigwe, N. E. (2019). Social Media Regulations and The Library in Nigeria. Library Research Journal, 3(1), 15-24. Retrieved from https://journals.unizik.edu.ng/index.php/lrj/article/view/49

Paslawsky, A. (2017). The Growth of Social Media Norms and the Governments' Attempts at Regulation. Fordham International Law Journal Volume, 35 (5) 1485-1542.Retrieved from https://ir.lawnet.fordham.edu/cgi/viewcontent.cgi?article=2604\&context=ilj

Pew Research Centre (2020). U.S Survey Research. Retrieved January 11, 2021 from https://www.pewresearch.org/methods/u-s-survey-research/

Radsch, C.C. (2013). Cyberactivism and Citizen Journalism in Egypt. Unpublished Doctoral 
Dissertation submitted to School of International Relations, American University - Washington DC.

The African Charter on Human and People's Rights, Article 9. Retrieved March 19, $2021 \mathrm{f} \mathrm{r} 0 \mathrm{~m}$ https://www.achpr.org/legalinstruments/detail?id=49

The Economic Times (2019, October 22) India plans to regulate social media as it can cause disruption. Retrieved March 18, 2021 from https://economictimes.indiatimes.com/news/economy/policy/india-plans-to-regulatesocial-media-as-it-can-cause-disruption/articleshow/71695590.cms

The United Nations General Assembly Resolution 59 (1) of December 14, 1946 R e $t$ r i e v e d March 19, 2021 from https://undocs.org/en/a/64/Add.1

The Universal Declaration of Human Rights of December 10, 1948. Retrieved March 19, 2021 from: https://www.un.org/en/about-us/universal-declaration-of-human-rights

Vareba, A.L., Nwinaene, V.P., Theophilus, S.B. (2017). Internet Censorship \& Freedom of Expression in Nigeria. International Journal of Mass Communication, 3 (2), 25-30.

Yar, M. (2018). A Failure to Regulate? The Demands and Dilemmas of Tackling Illegal Content and Behavior on Social Media. International Journal of Cyber-security, Intelligence \& Cybercrime, 1 (1), $5-20$.

Mclaughlin, T. (2018) How WhatsApp Fuels Fake News and Violence in I n d i a . R e t r i e v e d February 19, 2020 from https://www.wired.com/story/how-whatsapp-fuels-fake-news-andviolence-in-india/ 